\title{
THE EFFECTIVENESS OF STORYTELLING STRATEGY TO IMPROVE STUDENTS' READING COMPREHENSION AT SECOND GRADES OF MTs AL-MA'ARIF 1 KABUPATEN SORONG
}

\author{
Doni Sudibyo \\ donisud@ unimudasorong.ac.id \\ Ari Wibowo \\ ariwibowo@unimudasorong.ac.id \\ Wa Riani Hatam \\ hatamriani@gmail.com
}

\section{Education University of Muhammadiyah Sorong, Indonesia}

\begin{abstract}
This research aimed to know the effectiveness of storytelling strategy to improve the students' reading comprehension at second grades of MTs Al-Marif 1 KabupatenSorong. Storytelling was one of the good strategy in teaching learning process especially in teaching reading, because it can make the student was easier to understand about the text/story. In this research, the researcher used Quasiexperimental design. The subject of this research was VIIIC as experiment class that consist of 30 students: 16 males and 14 females, and VIIIB as control class that also consist of 30 students: 15 males and 15 females. The instruments were collected by using test (pre-test and post-test). The form of the test was essay and true false question. After giving the pre-test to students, the researcher gave the treatment and the steps in teaching learning process were: (1) the teacher divides the student into four groups, one group consist of 7-8 students; (2) the teacher divides the story of narrative text in each group; (3) teacher tell the story by using gesture, tone of voice and movement in the text/story; (4) after tell the story, teacher writes the questions the whiteboard; (5) teacher gave 15-20 minutes in every group to discuss the answer of the questions, then teacher ask one of students in each groups to read their answers. After giving the treatment, the researcher gave the post-test. The researcher used to analyze the result that the students got. Based on the finding in this research, the researcher can conclude that the alternative hypothesis (Ha) was accepted and null hypothesis (Ho) was rejected or it can be said that Storytelling Strategy was effective to improve the student's reading comprehension at the second grade of MTS AlMa'arif 1 KabupatenSorong. It was supported by the result which show that the value of was 2,356 and the value of from the df (58) on degree of significance of $5 \%$ was 2.00. It means that the value of is higher than the value of
\end{abstract}

Keywords: Story telling Strategy, Reading Comprehension. 


\section{INTRODUCTION}

Reading is one of the important skills in English. In many situations, reading is considered an indispensable channel of communication in an ever widening world. It is the process of recognition, interpretation and perception of written or printed materials. Since reading is very important skill for the students, great attention should be paid to the teaching of reading, particularly to the teacher's role in reading activities. Sibarani (2001:2) states that the important role in the classroom teaching is the teachers. It is due to the fact that a teacher has an important role in teaching especially in reading.

In Indonesia itself, the government has made some efforts to obtain human resources who are able to understand and master English well. The department of national education also has determined that the ability to be owned by the students of Indonesian are to understand and express the information, ideas, feelings and can develop science, technology and culture with the use of English language. One of the efforts of government and department of national education to obtain human resources who able to understand and master English well they have applied English as a general lesson which begin from the elementary school level until university.

Based on the researcher's observation in Mts Al-Ma'arif 1 Kabupaten Sorong, the researcher found that most of the students in the school have problem in reading comprehension. There are some factors that influence the problems. They are, firstly about the technique is used by the teacher. The technique is used by the teacher are monotonous, so that the students get bored even some of the students felt sleepy while learning process. Then, the teaching way of the teacher, The teacher just ask the students to do the task without ask them to read the text, so that the student's reading ability of Mts Al-Ma'arif 1 Kabupaten Sorong is low and the last about the students who consider that English is difficult, because the written and how to read it is different.

Even though reading comprehension skill has been taught for a long time to the Junior High School students, but still many of the Junior High School graduates are not able to read and understand even the simple written forms in English. This fact is so concerning that the researcher is very interested to conduct a research by the using one of the strategy to improve the students' reading comprehension in the Junior High School students, especially in Mts Al-Ma'arif 1 Kabupaten Sorong.

On this research, the researcher is going to make a situation where the students feel enjoy in learning process. The researcher will apply the storytelling strategy to know the student's reading comprehension at the second grade of Mts Al-Ma'arif 1 Kabupaten Sorong. Storytelling is the interactive art of using word and action to reveal the elements and images of a story while encouraging the listener's imagination. 
Children have an innate love of stories. Stories create magic and a sense of wonder at the world. Then, stories teach us about life, ourselves and etc. To make the students understand or master about the meaning of stories, the writer will use storytelling strategy, because it is a unique way to students to develop their understanding. Based on the explanation about the strategy above, the researcher hope it will help the students in teaching reading comprehension. The ways to apply the storytelling strategy will be explained in the next chapter.

\section{LIRATURE REVIEW}

\section{Previous Related Study}

First research is conducted by Umiyati (2011) The aimed of this research is to find out the empirical evidence of the differences between students' achievement in learning reading which is concerned with descriptive text by using small group interaction and whole class teaching at seven grade of SMP Sunan Bonang, Tangerang. This is an experimental research, the writer taught two different classes employing two different teaching technique. The writer administered a pre-test to know that the classes have relatively the same background knowledge in the research variable and a post-test to find out the growth of score as the measurement of reading comprehension. There is significant difference between achievements in learning reading which is concerned with descriptive text by using small group interaction. So, it means that the usage of Small Group Interaction in Teaching Reading Comprehension is effective.

Second study by Jill Eck (2006) in his study entitled "An Analysis of the Effectiveness of Storytelling with Adult Learners in Supervisory Management". The purpose of this study is to research and document how storytelling as a teaching and learning method has an impact on the learning and information retention of adult students who are enrolled in the Supervisory Management Program at Western Wisconsin Technical College (WWTC). To further examine the effectiveness of storytelling as a teaching pedagogy and learning method, a study was conducted with 17 adult learners who are enrolled in the Supervisory Training program at a Wisconsin technical college. Subsequent this lesson, an Opinion/reaction survey is administered to measure the learners experience with the storytelling activity. Items included on the survey include attention fixation, visualization, personal identification, and information transferability among others. In addition, a post-test on the course content is administered a week later to measure the amount of information retained from the storytelling lesson. The conclusions of this study are highly congruent with the learning theories of storytelling as an effective learning tool and teaching method. The findings of the study indicate that storytelling has a powerful impact on learning, especially as it relates to theories that espouse the experiential characteristics of storytelling and learner information retention. 
Third study by Uswatun Khasanah (2011) The research is aimed to describe teaching listening skill through story telling can improve listening skill, the second purpose is to describe the procedures of teaching listening skill through storytelling and the third is to describe the challenges on implementing storytelling in the listening class. In this research, storytelling is used to increase students' listening in learning English. This research was carried out at MTs N Klego Boyolali especially in class VIII A that consists of 22 students. In collecting the required data, the writer did observation, test, and documentation. There were two cycles in this classroom action research. In which, each cycle are divided to four procedures namely; planning, acting, observing and reflecting and consists of two meetings. Based on the research findings, it can be concluded that the process of teaching listening using storytelling is to improve the students' listening skill and to motivate the students to be active in the classroom. The mean score of pre-test was 43,40 to 60 in post test in first cycle and pre test in 58,86 to 73,40 in post test in second cycle. The students' score was getting better in each cycle. It indicates that the students' listening skill was improved. Therefore, it is better for the students to study English carefully through practice and experience, and to be active and creative in learning English.

Those three of thesis written from the thesis above, have similarities among:

1. The first study above, the writer used reading comprehension and experimental method in her research. Then the technique in collecting the data is used test by giving pre test and post test.

2. The second study, the writer using storytelling in his research. The writer also gave the test to collecting the data.

3. The third study, the writer using storytelling in her research. And, the writer chose the second grade as her population and sample and then using test to collecting the data. However, the differences are the setting of the study, the participant of the research, the type of the media used in teaching learning and the design where used in the study. In third study, the writer used classroom action research in her research.

\section{Some Pertinent Ideas}

\section{Reading}

According Leipzig (2007:1) stated that reading is a multifaceted process involving word recognition, comprehension, fluency and motivation. Other researcher Broughton (2003:90) states that reading is essentially an intellectual skill; this is the ability to correlate the black marks on the paper by way of the formal elements of language, they can say the words as sound, with meanings which those words symbolize. Reading skill it was pointed out that reading involves correlating elements of language with meaning. The most familiar of all elements of language are "wordse and it must be quiet clear that part of what is involved in understanding a text is understanding the meanings of individual words in that text. 
Furthermore, concerning about reading Patel \& Jain (2008:113) states that reading is the most activity in language class. Reading is not only a source of information and pleasurable activity but also as a means of consolidating and extending one's knowledge of the language. Reading is very necessary to widen the mind and gain and understanding of the foreign culture. Reading is certainly an important activity for expanding knowledge of a language.Based on the definition above the researcher can conclude that reading is very important for the students, because they can get a lot of information from the text that they read. Beside that they can also consolidating and extended their knowledge about a language

Elizabeth et al. (2000:14) states that Comprehension is the process of deriving meaning from connected text. It involves word knowledge (vocabulary) as well as think and reasoning. Therefore, comprehension is not a passive process, but an active one. The reader actively engages with the text to construct the meaning. This active engagement includes making use of prior knowledge. It involves drawing inferences from the words and expressions that a writer uses to communicate information, ideas and viewpoints. Recent studies have focus on how readers use their knowledge and reasoning to understand the texts. The term comprehension strategies are sometimes used to refer to the process of reasoning. The good readers are aware of how well they understand a text while reading and also take active steps to overcome difficulties in comprehension and information is need.

Based on the definition above, the researcher conclude that reading comprehension is useful to help the students for gaining the information about the text that they read. Reading also can evaluate students' vocabulary and then they also can interpret the meaning. Therefore, in this present of study the reading comprehension is defined as the process of constructing meaning from the text which is used one type of reading that is reading for specific information. It is an active activity that tries to catch or identify the idea of the text, the specific information whether it is about detail express or detail implied and textual reference.

\section{Storytelling Strategy}

Storytelling can be defined as a human experience that allows us to convey, through the language of words, characteristics of ourselves and others and the world. This world can be real or imagined. National Storytelling Network (2006), determines that storytelling as an interactive art of using words and actions to reveal the elements and images of content while encouraging the learner's imagination.

Furthermore, Mokhtar et al (2010: 48) states that storytelling is a technique that offers opportunities to practice organizing, categorizing, and remembering information concurrently with practice in predicting, summarizing, comparing and contrasting 
information on all academic communication functions and reading comprehension strategies. Otherwise, they state that reading passages are better understandable and more accurately recalled by storytelling.

Based on the definition above, the researcher conclude that storytelling strategy can help the students in achieving the educational goals because success in retelling enhances students' mental efficiency and helps to overcome obstacles and to gain knowledge by themselves.

\section{METHOD}

\section{Design and Samples}

Research can be defined as the process of problem solving. To solve the problem, the researcher needs a method. The choice of the method depends on the objective of the research. Related to this research, the researcher used Quasi-experimental design, a type of research design which included experimental and control groups.

\section{Population}

Population was the whole subject of the research (Arikunto, 2009:91). The population of this research was the second grade of Mts Al-Ma'arif 1 Kabupaten Sorong. There are 3 classes that consist of 92 students.

\section{Data Collection}

In this research, the researcher used some instruments (pre-test and post-test) to collect the data.

\section{Pre-test}

In order to examine the equivalence of the achievement in reading comprehension skills both of classes in this research, the experiment class and the control class were given the same reading pre test. The aims of tests was to find out the students score before the treatment were given to the experiment class by using Storytelling Strategy.

\section{Post-test}

After given the treatment, the researcher give post-test to the experiment class and control class. The test is conducted to find out whether the use of storytelling strategy effective to impact the student's reading comprehension in teaching English or on the contrary. 


\section{Procedure}

\section{Observation}

The researcher was observed eight class when the researcher did practice yard (PPL) in the school.

\section{Pre-test}

The researcher gave pre-test for measured the achievement of students' reading comprehension. The researcher gave 12 questions to students answer. The researcher gave same test to both of classes, the control class and the experiment class.

\section{Treatment}

After give pre-test to both of the groups, series of treatment was given to the experiment class. In this study the treatment used storytelling strategy in teaching reading comprehension. Meanwhile the control group was given without strategy. There were some steps about the implementation of storytelling Strategy. They were:

1. The teacher divides the students into four groups, one group consist of 7-8 students.

2. Teacher divides the story of narrative text in each groups

3. Teacher tells the story by using gesture, tone of voice and movement in the text/story, so that the students are easier to understanding the story.

4. After tell the story, teacher write the questions in the whiteboard.

5. Teacher gave 15-20 minutes in every group to discuss the answers of the questions, the teacher ask one of student in each group to read their answer. For the group that collect many point will be gotten the reward by the teacher.

Post-test

The last, after given the treatment the researcher give post-test to the experiment class and control class to know the result of it. The researcher gave 12 questions to students answer. The writer gave same test to both of classes, the control class and the experimental class.

\section{DISCUSSION}

The calculation results of experiment class show the significant improvement of student's reading comprehension by using Storytelling Strategy. Meanwhile, the calculation result of control group also showed the improvement of the student's reading comprehension, but it was not significant. It may be caused by the fact that they still remember what they have done in the pre test.

The comparison score of pre-test and post-test in experiment and control class show that the lowest score in pre-test, both of two classes got the same score (27).But after 
the researcher gave treatment, the score of experiment class was increaser than control class. It can be seen in the result score of post-test, the lowest score of experiment class got 50 while the lowest score of control class got 37.

To find about the result computation of t-test value, the researcher collected the data from getting score of pretest and post-test and taken three-four digit behind coma, the significant achievement in learning reading comprehension between the students who were taught by using Storytelling Strategy (Experiment class) and the students who were taught without using Storytelling Strategy (Control Class). On the other hand, if

$<\quad$ the alternative hypothesis (Ha) was rejected. It means that there was not a significant achievement in learning reading comprehension between the students who were taught by using Storytelling Strategy and the students who were taught without using Storytelling Strategy. Based on the explanation and the result who was

the researcher got in this research, or 2,356 2.00. It means that the Alternative hypothesis (Ha) was accepted. Therefore, the researcher can conclude that Storytelling was effective to improve the students' reading comprehension at the second grade of MTs Al-Ma'arif 1 Kabubaten Sorong.

\section{CONCLUSION AND SUGGESTION}

The result discussion throughout the present Experiment Research which dealt with the Effectiveness Storytelling Strategy to improve the student's reading comprehension in the second grade students of MTs Al-Ma'arif 1 Kabupaten Sorong could finally be conducted in this chapter. The findings of this reserach could be importantly give some convenience for the teachers and for the students in English teaching and learning process.

After analyzed the data the researcher can conclude that through storytelling, it can help the students to improve in their reading comprehension. Storytelling was the oneof the good strategy in teaching English especially in teaching reading process. It is supported bythe result that the researcher got in this research. Based on the research finding and the conclusion above, the researcher would like to suggest to the teacher that should motivate the students to study English seriously, and for the students should more practice their English skill especially Reading Skill. 


\section{References}

Al-Mansour, N. (2011). The Effect of Teacher's Storytelling Aloud on the Reading Comprehension of Saudi Elementary Stage Students. Saudi Arabia, Riyadh: King Saud University.

Arikunto, S. (2003). Dasar-Dasar Evaluasi Pendidikan. Jakarta :PT Rineka

Arikunto, S. (2010). Prosedur Penelitian Suatu Pendekatan Praktik. Jakarta:Rineka Cipta.

Broughton, G. (2003). Teaching English as a Foreign Language. New York: Routledge.

Campbell, Donald, T. and Stanley, M. (1996). Experimental and Quasi Experimental Design for Research. Chicago: Rand McNally.

Elizabeth. S. Pang. 2000. Teaching Reading. International Bureau of Education.

Eder, D. (2007). Bringing Navajo storytelling practices into schools: The importance of maintaining cultural integrity. Anthropology and Education . 38, (3), 278-296.

Ellis, G. \& Brewster, J. (2002). Tell it again! The new storytelling handbook for primary teachers. New York: Longman.

Grabe,W. \&Stoller, F.L (2002) Teaching and Researching Reading. New York: Pearson Education.

Hiebert, H.et al. (2005). Teaching and Learning Vocabulary. London : LEA.

Harmer, J. (2001). The Practice of English Language Teaching. China: Longman.

Julian and Richard. (2004). Extensive Reading Activities for Teaching Language. New York: Cambridge.

Lordly, D. (2007). Once upon a time: Storytelling to Enhance Teaching and Learning. Canadian Journal of Dietetic Practice and Research. 68,(1), 30-35.

Ministry of Education (2006). English for Palestine Curriculum, Student's Book (fouth ed.). Grade, Macmillan: UK.

Patel, M.F., Jain, M. and Praveen. (2008). English Language Teaching (Methods, Tools and technique). Jaipur : Sunrise. 
Shelly .J. (2010). Read it again please! The importance of story time. Available in : http://www.awakeparent.com/Shelly/importance-of-story-time [28 September 2017]

Scott, et.all. (2004). Teaching English to Children. London: Longman.

Sugiyono. (2007). MetodePenelitian Kuantitatif Kualitati dan R\&D. Bandung. Alfabeta.

Suharsimi and Arikunto, (2009). ManajemenPenelitian. Jakarta. Rineka Cipta.

Setyosari,P. (2013). Metode Penelitian Pendidikandan Pengembangan. Jakarta :Kencana Prenadamedia Group.

Setiyadi, A. (2006). Metode Penelitian Untuk Pengajaran Bahasa Asisng :Pendekatan Kuantitatif dan Kualitatif. Yogyakarta: GrahaIlmu.

Umiyati. (2011). The Effectiveness of Using Small Group Interaction in Teaching Reading Comprehension. A research report. Jakarta: Unpublished paper.

Mokhtar, et al. (2010). The Effectiveness of Storytelling in Enhancing Communicative Skills in Foundation English course. Centre of General Studies, Malaysia: University Kebangsaan. Available at: www.sciencedirect.com [20 desember 2016].

Maynard, B. (2005). The Importance of Story. Available in :http://subversiveinfluence.com/2005/01/the-importance-of-story/ [20 desember 2016]. 